\title{
ANALYSIS OF EFFECT OF QUALITY OF SERVICE ON CUSTOMER SATISFACTION ON FLIGHT OPERATION PT LION AIR IN TERMINAL I AIRPORT SOEKARNO HATTA
}

\author{
Abi Prasidi' ${ }^{1}$, Agus Yuliyanto ${ }^{2}$ \\ 1. STMT Trisakti, 2. STMT Trisakti \\ $\bowtie$ corresponding author: prasidi393gmail.com
}

\begin{abstract}
The purpose of this research is to know the influence of service quality (tangible, reliability, responsiveness, assurance, and emphaty) partially or simultaneously to customer satisfaction level and to know more dominant influence from tangible, reliability, responsiveness, assurance, and empathy) to the level of customer satisfaction on PT.Lion Air flight operation in Terminal I of Soekarno Hatta Airport. In this study how the influence of service quality (service quality) seen from five dimensions: tangible, reliability, responsiveness, assurance, and empathy to the satisfaction of airline service customers PT. Lion Air. While the hypothesis of this study is the quality of service has a significant influence on customer satisfaction of airline services PT.Lion Air. The results showed that service quality seen from five dimensions: tangible, reliability, responsiveness, assurance, and emphaty simultaneously and partially significant effect on customer satisfaction of PT.Lion Air flight service. Variables that have significant influence is assurance, as well as the most dominant effect on customer satisfaction.
\end{abstract}

Keywords: Tangible, Reliability, Responsiveness, Assurance, Emphaty and Customer Satisfaction

\section{Introduction}

To be a competitive company must meet several criteria, one of the criteria is customer satisfaction through Internal Customer Service (customer service in one company, either between divisions or to leadership and staff) and External Customer Service (customer service that is consumer ), where the services within the company moving well, automatic service to customers will also be better that is dynamic and flexible which is strongly influenced by the advances achieved in telecommunications technology and information technology as well as manually or orally in detail. During this time PT.Lion Air Company runs straight between many other similar companies, and so far also Lion Air airlines "accompany" the wider community, especially for the citizens of Indonesia who like to travel for his needs. The purpose of this research in 
general is to know how far the quality of service especially to analyze the influence of quality of service which consist of (tangible, reliability, responsiveness, assurance, and empathy) to PT.Lion Air customer's satisfaction on flight operation at Soekarno-Hatta Airport, and to analyze the influence of which variables are dominant from service quality (tangible, reliability, responsiveness, assurance, and empathy) to customer satisfaction of PT.Lion Air Airlines specially in flight operation of Terminal I of Soekarno Hatta Airport. Effective marketing (effective marketing) actually resulted in the opposite of creating value satisfaction. Various research and marketing and service literature reveals that services have four distinct characteristics that distinguish goods and services called IHIP: Intangibility, Heterogeneity, Inseparability and Perishability (Fandy Tjiptono and Gregoreus Chandra, 2005). The main factors that affect the quality of service are: expected services and services perceived / perceived. As an example of Emphaty which states that can be felt because a total treatment in accordance with the theory of TQM service management (Total Quality Management) is specified into implementation with the theory of service TQS (Total Quality Service). And Emphaty is here to share the feel of customer kesulitasn.

\section{Method}

The research was conducted with quantitative descriptive approach and the type of research empirical study supported by survey. The nature of this research is explanatory research (explanatoring research) is a study that aims to describe and explain the nature of an ongoing situation at the time of the study conducted and examined the causes of the symptoms. The population in this study are passengers who have used the services of PT.Lion Air flights and officers / staff on the flight operation which also handles service activities in ground operation. Sampling technique in this research is by purposive sampling method. Purposive sampling is a deliberate intake technique. samples were taken not randomly, but determined by the researchers themselves. The criteria 
used for sample determination are Lion Air flight operation officer, customers who have ever used Lion Air flight services, customers who have used Lion Air flight services. Technique of collecting data in this research is done by giving interview or questionnaire. The list of questions concerns the quality of service and customer satisfaction using the services of PT.Lion Air flights. Source of data collection used in this research is primary data. Primary data is data obtained and collected from Lion Air airline customers in the flight operation of Soekarno-Hatta Airport based on the questionnaire. The independent variable $(\mathrm{X})$ is a service quality consisting of dimensions of tangibles (physical evidence), realibility, responsiveness, assurance (assurance), and emphaty (empathy). Dependent variable (Y) is customer satisfaction of Lion Air. Operational definition of variables

\section{Discussion and Result}

To know the result of research, then do some test method. Some of them are validity and reliability tests. Based on the question items given in the questionnaire submitted to passengers using the aircraft service or Lion Air fleet, then tested the validity of the question items. Result of validity test by using program SPSS Ver.16.0 which can be seen in attachment. Correlation technique used is product moment correlation. The measurement criterion is pvalue $<0,05$ then the question item is declared valid. Reliability test is used in order to know the nature of the measuring instrument used, in the sense that the measuring instrument is accurate, stable and consistent. The instrument used in the study is said to be reliable if it has a coefficient of cronbach 'alpha greater than 0.60. Reliability test results from research variables using Cronbach's alpha with the help of SPSS version 16.0 is as follows :

Table 1. Reliability Test Results

\begin{tabular}{|l|l|l|l|}
\hline Variabel & Cronbach's Alpha & Critical Value & Information \\
\hline Tangibles $\left(\mathrm{X}_{1}\right)$ & 0,570 & 0,60 & Reliabel \\
\hline Reliability $\left(\mathrm{X}_{2}\right)$ & 0,570 & 0,60 & Reliabel \\
\hline Responsiveness $\left(\mathrm{X}_{3}\right)$ & 0,604 & 0,60 & Reliabel \\
\hline
\end{tabular}


Table 1, Cont. Reliability Test Results

\begin{tabular}{|l|l|l|l|}
\hline Assurance $\left(\mathrm{X}_{4}\right)$ & 0,600 & 0,60 & Reliabel \\
\hline Emphaty $\left(\mathrm{X}_{5}\right)$ & 0,722 & 0,60 & Reliabel \\
\hline Customer satisfaction $(\mathrm{Y})$ & 0,550 & 0,60 & Reliabel \\
\hline
\end{tabular}

Source: Primary Data is processed, 2017

From these results it can be seen that all the question items about the variabletangibles $\left(\mathrm{X}_{1}\right)$, reliability $\left(\mathrm{X}_{2}\right)$, responsiveness $\left(\mathrm{X}_{3}\right)$, assurance $\left(\mathrm{X}_{4}\right)$, emphaty $\left(\mathrm{X}_{5}\right)$, dan customer satisfaction $(\mathrm{Y})$ shows a reliable value because of the value Cronbach's alpha> 0,60. The normality test aims to test whether in the regression model, the confounding variable has a normal distribution. With computer tool SPSS program. 16.0 can researchers submit the results. This multicollinearity test is used to determine whether there is a meaningful relationship between each independent variable in the regression model. The result of analysis using SPSS version 16.0 is as follows :

Table 2. Multicollinearity Test Results

\begin{tabular}{|l|l|l|l|l|l|}
\hline Variables & $\begin{array}{l}\text { Tolerance } \\
\text { value }\end{array}$ & Criteria & VIF & Criteria & Keterangan \\
\hline Tangibles $\left(\mathrm{X}_{1}\right)$ & 0,470 & 0,10 & 1,613 & 0,10 & Not occur \\
Reliability $\left(\mathrm{X}_{2}\right)$ & 0,501 & 0,10 & 1,551 & 0,10 & Not occur \\
Responsiveness & 0,871 & 0,10 & 1,030 & 0,10 & Not occur \\
(X) & & & & & \\
Assurance $\left(\mathrm{X}_{4}\right)$ & 0,482 & 0,10 & 1,575 & 0,10 & Not occur \\
Emphaty $\left(\mathrm{X}_{5}\right)$ & 0,504 & 0,10 & 1,516 & 0,10 & Not occur \\
\hline
\end{tabular}

Source: Primary data is processed, 2017

The result can be seen that all independent variables namelytangibles $\left(\mathrm{X}_{1}\right)$, reliability $\left(\mathrm{X}_{2}\right)$, dan responsiveness $\left(\mathrm{X}_{3}\right)$, assurance $\left(\mathrm{X}_{4}\right)$ andemphaty $\left(\mathrm{X}_{5}\right)$ shows no multicollinearity due to tolerance value $>0.10$ and value $\mathrm{VIF}<10$. The test used in Heteroskidasticity analysis is by Glestjer test. The result of analysis using SPSS version 16.0 is as follows :

Table 3. Heteroscedasticity Test Results

\begin{tabular}{|l|l|l|l|}
\hline Variables & Probability & Significant Criteria & Information \\
\hline Tangibles $\left(\mathrm{X}_{1}\right)$ & 0,084 & 0,05 & Not occur \\
Reliability $\left(\mathrm{X}_{2}\right)$ & 0,221 & 0,05 & Not occur \\
Responsiveness $\left(\mathrm{X}_{3}\right)$ & 0,522 & 0,05 & Not occur \\
Assurance $\left(\mathrm{X}_{4}\right)$ & 0,816 & 0,05 & Not occur \\
Emphaty $\left(\mathrm{X}_{5}\right)$ & 0,781 & 0,05 & Not occur \\
\hline
\end{tabular}

Source: Primary data is processed, 2017 
From the table it is said that the probability value $>0.05$, so that the independent variable tested, that tangibles $\left(\mathrm{X}_{1}\right)$, reliability $\left(\mathrm{X}_{2}\right)$, andresponsiveness $\left(\mathrm{X}_{3}\right)$, assurance $\left(\mathrm{X}_{4}\right)$ andemphaty $\left(\mathrm{X}_{5}\right)$ showed no heteroscedasticity. Multiple Linear Regression Analysis is used to test the influence of independent variables istangibles $\left(\mathrm{X}_{1}\right)$, reliability $\left(\mathrm{X}_{2}\right)$, andresponsiveness $\left(\mathrm{X}_{3}\right)$, assurance $\left(\mathrm{X}_{4}\right)$ andemphaty $\left(\mathrm{X}_{5}\right)$ against the dependent variable of customer satisfaction (Y). Result of analysis by using SPSS program obtained result as shown in table IV.5. The F test is used to test the effect of independent variables ietangibles $\left(\mathrm{X}_{1}\right)$, reliability $\left(\mathrm{X}_{2}\right)$, andresponsiveness $\left(\mathrm{X}_{3}\right)$, assurance $\left(\mathrm{X}_{4}\right)$ andemphaty $\left(\mathrm{X}_{5}\right)$ simultaneously (simultaneously) to the dependent variable that is customer satisfaction (Y). The result of $\mathrm{F}$ test analysis by using SPSS program can be summarized in Table 4.

Table 4. Results Test Analysis F

\begin{tabular}{|l|l|l|l|l|l|l|}
\hline Information & $\begin{array}{l}\text { Sum of } \\
\text { Squares }\end{array}$ & Df & $\begin{array}{l}\text { Mean } \\
\text { Square }\end{array}$ & F hitung & Sig. & Conclusion \\
\hline Regression & 456,116 & 4 & 92,422 & 34,552 & 0,000 & H0 rejected \\
Residual & 245,231 & 93 & 2,160 & & & \\
Total & 613,430 & 98 & & & \\
\hline
\end{tabular}

Source: Primary data is processed, 2017

$\mathrm{T}$ test is used to test the significance of the effect of independent variables ietangibles $\left(\mathrm{X}_{1}\right)$, reliability $\left(\mathrm{X}_{2}\right)$, andresponsiveness $\left(\mathrm{X}_{3}\right)$, assurance $\left(\mathrm{X}_{4}\right)$ andemphaty $\left(\mathrm{X}_{5}\right)$ partially to the dependent variable that is customer satisfaction (Y). The result of $\mathrm{t}$ test analysis using SPSS program can be summarized in Table 5

Table 5. Results Test Analysis t

\begin{tabular}{|l|l|l|l|l|l|l|}
\hline Variable & $\begin{array}{l}\text { Unstandardized } \\
\text { Coefficients }\end{array}$ & B & $\begin{array}{l}\text { Standardized } \\
\text { Coefficients }\end{array}$ & T hitung & Sig. & Conclusion \\
\hline & Error & Beta & & & \\
\hline Constant $)$ & 0,317 & 1,654 & & 0,258 & 0,797 & \\
\hline Tangibles $\left(\mathrm{X}_{1}\right)$ & 0,204 & 0,175 & 0,217 & 2,727 & 0,008 & H0 rejected \\
\hline Reliability $\left(\mathrm{X}_{2}\right)$ & 0,167 & 0,076 & 0,182 & 2,325 & 0,022 & H0 rejected \\
\hline Responsiveness $\left(\mathrm{X}_{3}\right)$ & 0,134 & 0,053 & 0,145 & 2,351 & 0,021 & H0 rejected \\
\hline Assurance $\left(\mathrm{X}_{4}\right)$ & 0,331 & 0,068 & 0,381 & 4,847 & 0,000 & H0 rejected \\
\hline Emphaty $\left(\mathrm{X}_{5}\right)$ & 0,160 & 0,062 & 0,201 & 0,603 & 0,011 & H0 rejected \\
\hline
\end{tabular}


Coefficient of Determination analysis is used to find out how big the contribution or influence given free variable that istangibles $\left(\mathrm{X}_{1}\right)$, reliability $\left(\mathrm{X}_{2}\right)$, andresponsiveness $\left(\mathrm{X}_{3}\right)$, assurance $\left(\mathrm{X}_{4}\right)$ andemphaty $\left(\mathrm{X}_{5}\right)$ against the dependent variable that is customer satisfaction (Y) shown by percentage.

\section{Conclusion}

Based on the results of research and analysis of data that has been implemented it can be drawn conclusion that there is a positive and significant influence of independent variables ietangibles $\left(\mathrm{X}_{1}\right)$, reliability $\left(\mathrm{X}_{2}\right)$, andresponsiveness $\left(\mathrm{X}_{3}\right)$, assurance $\left(\mathrm{X}_{4}\right)$ andemphaty $\left(\mathrm{X}_{5}\right)$ partially to dependent variable that is customer satisfaction (Y). There is a significant influence of independent variables ietangibles $\left(\mathrm{X}_{1}\right)$, reliability $\left(\mathrm{X}_{2}\right)$, andresponsiveness $\left(\mathrm{X}_{3}\right)$, assurance $\left(\mathrm{X}_{4}\right)$ andemphaty $\left(\mathrm{X}_{5}\right)$ simultaneously (in unison) to the dependent variable that is customer satisfaction $(\mathrm{Y})$. Assurance variable $\left(\mathrm{X}_{4}\right)$ is the dominant variable affecting customer satisfaction (Y), because the value of regression coefficient is greatest among other variables, seen from standardized coefficients beta of 0.381 . The contribution of independent variables are tangibles $\left(\mathrm{X}_{1}\right)$, reliability $\left(\mathrm{X}_{2}\right)$, and responsiveness $\left(\mathrm{X}_{3}\right)$, assurance $\left(\mathrm{X}_{4}\right)$ and emphaty $\left(\mathrm{X}_{5}\right)$ to dependent variable, customer satisfaction $(\mathrm{Y})$ is $63.6 \%$ while the rest $(100 \%-63.6 \%)=36.4 \%$ influenced by other factors outside the variables studied. The suggestions that writers can convey in this study are all elements of service quality dimensions have a positive influence on customer satisfaction, so Lion Air Airlines need to pay more attention to the service quality dimensions as well as seek a breakthrough that can improve the performance and service especially in maintaining relationships with customers or passengers and always given training which is constantly sustainable. Tangible, reliability, responsiveness, assurance, and empathy, which can affect the dependent variable of customer satisfaction, for example, service efficiency and service effectiveness, in order to better complement the research because 
there are still other independent variables outside of this study that may affect consumer satisfaction.

\section{References}

Djarwanto,Ps. 1998. Statistik Induktif. BPFE: Yogyakarta.

Ferrinadewi, Erna. 2005. Atribut Produk yang Dipertimbangkan dalam Pembelian Kosmetik dan Pengaruhnya pada Kepuasan Konsumen di Surabaya. Jurnal Manajemen dan Kewirausahaan, Volume Ketujuh, No.2.

Ghozali, Imam. 2005. Aplikasi Analisis Multivariate dengan Program SPSS. EdisiKetigaSemarang :BadanPenerbitUniversitasDiponegoro.

Hasibuan,Malayu.2008.Manajemen Sumber Daya Manusia (edisi revisi,cetakan ketujuh). Jakarta: Bumi Aksara.

Muhammad Resky \& Simarmata Juliater. 2014. Fungsi Dan Kelemahan Unit Operasi Pelayanan Di Bandara. Jakarta: STMT Trisakti.

Marina Sandriana, Darmawati Andi \& Setiawan Indra.2014. Pengaruh Kualitas Pelayanan Terhadap Loyalitas Pelanggan Pada Perusahaan Penerbangan Full Service Airlines. Jakarta: STMT Trisakti.

Malthis, Robert L \& John H. Jackson.2001. Human Resource Management Manajemen Sumber Daya Manusia (edisi Sepuluh, Terjemahan: Diana Angelica). Jakarta: Salemba Empat.

Pahrudin Cecep, Warsito Tito \& Chandra Adi. 2016. Kepuasan Kapten Pilot Dan Co Pilot Terhadap Kinerja Flight Operation Officer. Jakarta: STMT Trisakti.

Riduwan \& Kuncoro.2008. Cara Menggunakan dan memakai Analisis Jalur (Path Analysis). Bandung: Alfabeta.

Rivai,Veithzal.2005. Manajemen Sumber Daya Manusia untuk Perusahaan (edisi kedua). Jakarta: Rajawali Pers.

Rivai,Veithzal.2005. Performance Appraisal. Jakarta: Raja Grafindo Persada.

Sarwono, Jonathan. 2006. Analisa Data Penelitian Menggunakan SPSS. Yogyakarta: Andi.

Singrimbun, Masri \& Sofyan Effendi. 1995. Metode Penelitian Survei (cetakan kedua). Jakarta: LP3ES.

Simamora, Henry.2004. Manajemen Sumber Daya Manusia (edisi ketiga, cetakan pertama). Yogyakarta: YKPN.

Sugiyono.2008. Metode Penelitian Administrasi (cetakan keenam). Bandung: Alfabeta.

Suliyanto.2005. Analisa Data dalam Aplikasi Pemasaran. Bogor: Ghalia Indonesia

Saribanon Euis, Rohana \& Amrizal. 2016. Kepuasan Jasa Transportasi Untuk Meningkatkan Loyalitas. Jakarta: STMT Trisakti.

Simarmata Juliater, Suryana Yuyus, Kaltum Umi \& Oesman M. Yevis. 2016. Airlines Customer Retention In Indonesia 2015. Jakarta: STMT Trisakti. 
Umar,H.2005.Riset Sumber Daya Manusia Dalam Organisasi (cetakan kelima). Jakarta: Gramedia Pustaka Utama.

Uyanto,S \& Stanislaus.2006. Pedoman Analisis Data dengan SPSS (edisi pertama, cetakan pertama). Yogyakarta: Graha Ilmu.

Umar,Husein. 2003. Riset Pemasaran dan Perilaku Konsumen. Jakarta: PT Gramedia.

Utari,Woro.2010. Model Kepuasan Pelanggan Sebagai Moderating Variabel Guna Meningkatkan Loyalitas Pelanggan pada MaskapaiPenerbangan, Jurnal Mitra Ekonomi dan Manajemen Bisnis, Vol.1,No. 2.

Yazid.1999. Pemasaran Jasa Konsep dan Implementasi. Cetakan Pertama. Yogyakarta: Ekonisia Fak. Ekonomi UII.

Zeithaml Valarei, A and Bitner, Mary, Jo. 2004. Service Markerting: Integrating Customer Focus Across The Fim. $3{ }^{\text {rd }}$ Edition. New York : McGraw Hill. 